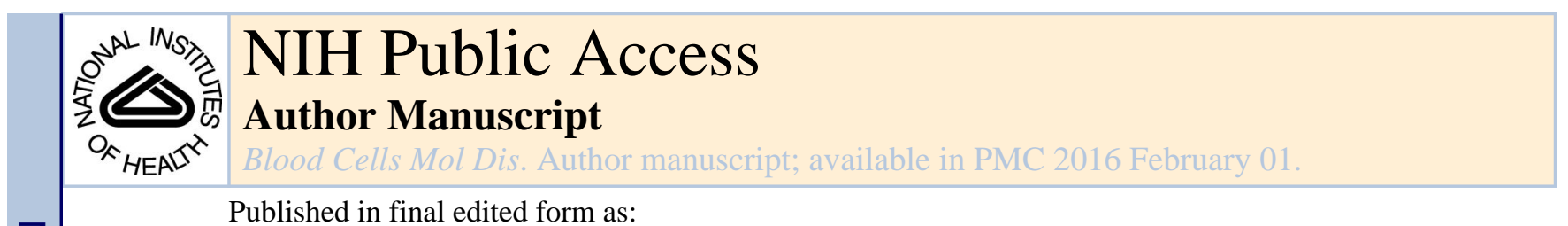

Published in final edited form as:

Blood Cells Mol Dis. 2015 February ; 54(2): 189-194. doi:10.1016/j.bcmd.2014.11.003.

\title{
Pulmonary Hypertension In Well-Transfused Thalassemia Major Patients
}

\author{
Antonella Meloni $^{\mathrm{a}, \mathrm{b}}$, Jon Detterich ${ }^{\mathrm{b}}$, Alessia Pepe ${ }^{\mathrm{a}}$, Paul Harmatz ${ }^{\mathrm{c}}$, Tom D Coates ${ }^{\mathrm{d}}$, and \\ John C. Wood ${ }^{b, e}$ \\ ${ }^{a} C M R$ Unit, Fondazione G. Monasterio CNR-Regione Toscana, Pisa, Italy \\ 'Division of Cardiology, Children's Hospital Los Angeles, Los Angeles, California, USA \\ 'Division of Gastroenterology, Children's Hospital Oakland, Oakland, California, USA \\ dSection of Hematology, Children's Hospital Los Angeles, Los Angeles, California, USA \\ eDepartment of Radiology, Children's Hospital Los Angeles, Los Angeles, California, USA
}

\section{Abstract}

The risk for pulmonary hypertension (PH) in thalassemia major (TM) patients remains controversial. We report echocardiography results from 60 TM patients: we evaluated the association between tricuspid regurgitation velocities (TRV), iron stores, and serologic markers of hemolysis and arginine dysregulation.

Patients were enrolled from August 2004 until May 2009. All parameters were inversely weighted by the number of exams.

TRV was comparable between sexes and it was uncorrelated with age. At the first exam, TR velocities at the upper limits of normal $(2.5-2.7 \mathrm{~m} / \mathrm{s})$ were observed in 8 patients. An abnormal TRV $(2.9 \mathrm{~m} / \mathrm{s})$ was found in 1 patient.

Borderline increases in TRV were associated with a reduced global arginine bioavailability $(\mathrm{R}=$ $-0.399 \mathrm{P}=0.005$ ), increased anemia (haemoglobin: $\mathrm{R}=-0.219 \mathrm{P}=0.0461)$, cardiac index $(\mathrm{R}=0.223$ $\mathrm{P}=0.0481$ ), and diastolic dysfunction ( $\mathrm{E} / \mathrm{A}: \mathrm{R}=0.289 \mathrm{P}=0.0088 ; \mathrm{E} / \mathrm{E}^{\prime}: \mathrm{R}=0.223 \mathrm{P}=0.0453$ ), but not hemolysis, iron overload and systolic function evaluated by Magnetic Resonance Imaging, and splenectomy.

Well-transfused TM patients have a lower risk for PH than thalassemia intermedia patients.

However, they do have vascular stressors that raise their lifetime PH risk to levels higher than for

(C) 2014 Elsevier Inc. All rights reserved

Address for correspondence: John C. Wood, Division of Cardiology, MS\#34, Children's Hospital of Los Angeles, 4650 Sunset Blvd, Los Angeles, CA, 90027-0034, 323361 5470, 323361 7317, jwood@chla.usc.edu.

CONFLICTS OF INTEREST

Dr Pepe has received speaker honoraria from Chiesi Farmaceutici, ApoPharma Inc. and Novartis. Dr. Harmatz has received research funding, honorarium and/or provided consulting support to Shire, BioMarin, Alexion, Novartis, and Genzyme. Dr Wood and Dr Coates receive research funding from Shire. Dr Wood is MRI consultant for Shire, Biomed Informatics, and ApoPharma.

Publisher's Disclaimer: This is a PDF file of an unedited manuscript that has been accepted for publication. As a service to our customers we are providing this early version of the manuscript. The manuscript will undergo copyediting, typesetting, and review of the resulting proof before it is published in its final citable form. Please note that during the production process errors may be discovered which could affect the content, and all legal disclaimers that apply to the journal pertain. 
the general population. Consequently, we support recommendations for annual echocardiographic screening and cardiac catheterization for persistent TRV above $3 \mathrm{~m} / \mathrm{s}$.

\section{Keywords}

thalassemia major; tricuspid regurgitant jet velocity; risk for pulmonary hypertension; echocardiography

\section{INTRODUCTION}

Pulmonary hypertension $(\mathrm{PH})$ is a disease of the pulmonary vasculature characterized by elevated pulmonary artery pressure and pulmonary vascular resistance. It is typically progressive, leading to right ventricular overload and eventually to right ventricular failure and premature death [1]. The increase in pulmonary vascular resistance is related to a number of progressive changes in the pulmonary arterioles, including: vasoconstriction, inflammation, in-situ thrombosis and proliferative remodelling of the pulmonary vessel wall. The gold standard for diagnosing pulmonary hypertension is a right heart catheterization (RHC) and measurement of blood pressure in the pulmonary arteries. Although RHC is now a relatively safe procedure, it is invasive and impractical to perform in patients for whom it is not clearly indicated. Because it is non-invasive, widely available and relatively inexpensive, echocardiography is frequently used to screen for $\mathrm{PH}$, monitor progression over time and allow identification of patients for whom diagnostic RHC is warranted [2]. Doppler echocardiography uses the peak tricuspid regurgitant (TR) jet velocity, which estimates the pressure difference between the right ventricle and right atrium using the modified Bernoulli equation [3].

Hemoglobinopathies, including thalassemias, have been recognized as one of the most common causes of PH worldwide [4]. The pathophysiology is multifactorial, characterized by chronic hemolysis, loss of splenic function (or splenectomy), hypercoagulability, vascular inflammation, liver dysfunction, hypoxemia, iron overload, left ventricular dysfunction, and increased cardiac output [5], [6], [7] and [8]. As a result, most studies clearly suggest a high prevalence of pulmonary hypertension in thalassemia intermedia patients [9] and [5].

However, regular transfusion therapy modifies pulmonary hypertension risk by preventing chronic tissue hypoxia, reduces chronic hemolysis and its negative effects on nitric oxide availability, and lowers circulating proinflammatory hormones such as placenta growth factor (PIGF) [10]. Aggressive chelation therapy is necessary to reduce cardiac and vascular iron deposition due to transfusions in order to lower cardiovascular oxidative stress and improve vascular reactivity [11] and [12]. As a result, some studies suggest that pulmonary hypertension is quite rare in well-treated thalassemia major (TM) patients [13] and [14], unlike thalassemia intermedia patients [15]. In contrast, Hagar et al reported that $57 \%$ of their hypertranfused thalassaemia patients had tricuspid regurgitation velocities (TRV) greater than $2.5 \mathrm{~m} / \mathrm{s}$ and concluded that chronic transfusions were not protective against $\mathrm{PH}$ [16]. Similarly, a multicenter study from the Thalassemia Clinical Research Network 
reported TRV $>2.5 \mathrm{~m} / \mathrm{s}$ in one third of chronically transfused patients and TRV $>3 \mathrm{~m} / \mathrm{s}$ in $8 / 148$ patients [17].

In the present study we report echocardiography results from 60 thalassemia major patients. In particular, we evaluated the association between TRV, iron stores, and serologic markers of hemolysis and arginine dysregulation.

\section{MATERIAL AND METHODS}

\section{Patient selection}

From August 2004 to May 2009 patients with a diagnosis of TM were enrolled in a combined cross-sectional and longitudinal trial probing for early predictors of cardiac dysfunction (EDICT study).

All patients had received $>8$ transfusions per year for at least 7 years. All had pulmonary function tests, magnetic resonance imaging (MRI) scans of the heart and liver, and blood tests performed within 10 days of a regularly-schedule transfusion to limit the confounding influence of anemia.

Results of exercise performance, pulmonary function, and electrocardiogram analysis have already been published [18], [19] and [20].

The protocol for the conduct of this study was approved by The Children's Hospital of Los Angeles' Committee for the Protection of Human Subjects.

We reviewed all digitally stored medical records from that study and selected the patients with one or more accurate measurements of tricuspid regurgitation jet by echocardiography. Sixty patients suitable for analysis were identified, for a total of 83 exams. The visits were scheduled within one week of transfusion and all patients underwent a MRI exam within 3 months. Average time delay between the two studies was $7.1 \pm 14.2$ days.

The medical records were reviewed also for demographic data and for hematologic and biochemical parameters, determined by routine laboratory methods, all measured within three months from the MRI. Blood parameters included complete blood count, plasma amino acids, LDH, cell free hemoglobin, and haptoglobin.

\section{Echocardiography}

Two dimensional and M-mode echocardiography, conventional Doppler echocardiography and tissue Doppler imaging (TDI) were performed at rest using an Philips IE33 echocardiography machine (Best, The Netherlands) using 2.5 and $5 \mathrm{MHz}$ curved array transducers. Standard 2D echocardiographic parameters of cardiac structure and function, Doppler assessment of pulmonary veins, mitral inflow, tricuspid inflow, left ventricular outflow tract, as well as tissue Doppler imaging at the mitral and tricuspid annulus were acquired by experienced echocardiography technicians with the patient in the left lateral position. Three to five beat averages were used for improved overall measurement accuracy. Continuous wave Doppler was used to measure the peak velocity of the TR jet at end- 
expiration. TR jet was only reported if a full envelope was recognized. At our institution, the upper limit of normal for TR jet is considered to be $2.7 \mathrm{~m} / \mathrm{s}$.

Left ventricular diastolic function was assessed according to the Nagueh et al guidelines [21]: early (E) and late (A) transmitral peak flow velocities were recorded. In patients with severe diastolic dysfunction, left ventricular filling occurs primarily in early diastole, creating an E/A ratio greater than 2.0. Early diastolic mitral annular velocity $\left(\mathrm{E}^{\prime}\right)$ was assessed by TDI and the ratio of mitral inflow $\mathrm{E}$ velocity to tissue Doppler $\mathrm{E}^{\prime}$ velocity was used to estimate $\mathrm{LV}$ filling pressure. Increased $\mathrm{E} / \mathrm{E}^{\prime}$ is a marker of abnormal $\mathrm{LV}$ filling and correlates with high left atrial pressure [22]. All echocardiograms were analyzed by the principal investigator (JCW).

The corrected pulmonary vascular resistance PVR(c) was also estimated [23]. PVR(c) was shown to identify the severity of PH and may be used to assess treatment response.

\section{MRI}

All MRI examinations were performed using a 4-element torso phased array coil and a 1.5 Tesla General Electric CVi scanner running system 9.1.

For cardiac and hepatic iron overload assessment, validated multiecho gradient-echo sequences were acquired. All images were processed using custom MATLAB routines (The Mathworks, Natick, MA) [24]. Region of interest (ROI) in the heart was restricted to the interventricular septum [25] while in the liver it encompassed the entire visible tissue [26]. The signal in each pixel within a ROI was fit to an exponential plus a constant model and the median of the distribution of R2* values was calculated. As recommended [27], liver R2 values [28] and R2* values [26] were converted to predicted liver iron concentration (LIC) using appropriate calibration curves.

For the evaluation of biventricular volumes and ejection fractions, fifteen serial short-axis steady-state free precession cine images were acquired during 8-second breath holds with slice thickness adjusted to span the heart. Images analysis was performed in a standard way using MASS 4.0 (Medis, The Netherlands), as previously described [29].

\section{Statistical analysis}

All analyses were performed using SAS JMP v. 5.1 statistical software (SAS Institute, Cary, NC).

All parameters were inversely weighted by the number of exams such that each patient contributed equally to correlation and group-wise analyses. All continuous variables were expressed as the mean \pm standard deviation (SD). The Shapiro-Wilks W test was applied to check the normality of the residual distributions.

For continuous values with normal distribution, comparisons between two groups were made by independent-samples t-test. First, Levene's test was applied to verify the homogeneity of variances (homoscedasticity). When the significance level of Levene's test was $<0.05$ and homoscedasticity could not be assumed, the Welch statistic was used. The 
Wilcoxon signed-rank test was applied for continuous values with non normal distribution. Correlation analysis was performed using Pearson's test or Spearman's where appropriated. In all tests, a 2-tailed probability value of 0.05 was considered statistically significant.

\section{RESULTS}

Patients were balanced with respect to sex (30 males and 30 females) and the mean age at the first exam was $25.2 \pm 9.4$ years (range: $9-47$ years). The cohort was $30.5 \%$ Chinese, 11.9\% other Southeast Asia (Vietnamese, Laotian, Filipino), 18.6\% Indian Subcontinent (Indian, Pakistani), 23.7\% Mediterranean (Italian, Greek, Cypriot), 8.5\% Middle Eastern (Iranian, Lebanese, Iraqi, Saudi). Seventeen patients had evidence of inactive hepatitis C and two patients smoked.

TRV was comparable between males and females $(2.12 \pm 0.29 \mathrm{~m} / \mathrm{s}$ vs $2.13 \pm 0.21 \mathrm{~m} / \mathrm{s}$; $\mathrm{P}=0.8032)$ and it was not correlated with age $(\mathrm{r}=0.002, \mathrm{P}=0.9828)$. At the first exam, TR velocities at the upper limits of normal $(2.5-2.7 \mathrm{~m} / \mathrm{s})$ were observed in eight patients. An abnormal TR jet $(2.9 \mathrm{~m} / \mathrm{s})$ was found in only 1 patient.

Table 1 shows the association between the TR jet and the variables used as markers of different pathological states representing risk factors in the development of PH. No correlation was detected between TR jet and markers of increased hemolytic rate: decreased haptoglobin and increased concentration of lactate dehydrogenase (LDH) in the blood. An haptoglobin lower than $25 \mathrm{mg} / \mathrm{dL}$ was found in the $40 \%$ of the cases.

The global arginine bioavailability (GAB), calculated as arginine divided by the sum of ornithine plus citrulline and serving as a more comprehensive concept of reduced NO synthetic capacity compared with systemic arginine levels, showed a significant negative correlation with TR jet $(\mathrm{R}=-0.399 ; \mathrm{P}=0.0050)$ (Figure 1$)$. The $\mathrm{GAB}$ was also significantly correlated to the $\mathrm{PVR}(\mathrm{c})(\mathrm{R}=-0.4056 ; \mathrm{P}=0.0063)$.

Hemoglobin and hematocrit were used as markers for anemia and only the hemoglobin showed a significant negative correlation with TRV ( $\mathrm{R}=-0.219 ; \mathrm{P}=0.0461)$ (Figure 2, up). Because the patient visits were timed early in the transfusion cycle, patients were generally not anemic. TRV showed a weak positive correlation with the cardiac index $(\mathrm{R}=0.223$; $\mathrm{P}=0.0481$ ) (Figure 2, bottom). Note that $44.3 \%$ of all examinations demonstrated cardiac index values above the upper limit of normal (dashed vertical line), including all of the patients with intermediate increases of TR velocity $(>2.5 \mathrm{~ms}$ and $<=2.7 \mathrm{~m} / \mathrm{s})$.

There was no correlation between TRV, total lung capacity (TLC), resting $\mathrm{O}_{2}$ saturation, diffusion capacity of the lung for carbon monoxide (DLCO) adjusted for hemoglobin and lung volumes, or lowest saturation during exercise testing.

TRV was not correlated with systolic function (volumes and EF evaluated by MRI) while it was significantly correlated with both the markers of diastolic function: $\mathrm{E} / \mathrm{A}$ ratio $(\mathrm{R}=0.289$; $\mathrm{P}=0.0088)$ and $\mathrm{E} / \mathrm{E}^{\prime}$ ratio $(\mathrm{R}=0.223 ; \mathrm{P}=0.0453)$ (Figure 3$)$. The patients with flow related increases in TR velocity had high E/A ratios but normal or low E/E' ratios. In contrast, the patient with iron cardiomyopathy and pulmonary hypertension had a high $\mathrm{E} / \mathrm{E}^{\prime}$ ratio. Overt 
left ventricular dysfunction ( $\mathrm{LV} \mathrm{EF}<56 \%$ ) was present in the $9.8 \%$ of cases, but only in those patients whose $\mathrm{T} 2 *$ was less than $10 \mathrm{~ms}$. TRV was not associated with serum ferritin levels, LIC or cardiac R2*.

Twenty-four (40\%) patients were splenectomized. Splenectomized patients were significantly older than non-splenectomized patients $(31.2 \pm 7.5$ years vs $21.8 \pm 6.8$; $\mathrm{P}<0.0001)$ but the two groups had comparable TRV $(2.10 \pm 0.23 \mathrm{~m} / \mathrm{s}$ vs $2.15 \pm 0.19$; $\mathrm{P}=0.3855)$.

$\mathrm{HCV}$ patients were significantly older $(33.5 \pm 7.1$ years vs $22.5 \pm 6.8 ; \mathrm{P}<0.0001)$ but the two groups had comparable TRV $(2.11 \pm 0.24 \mathrm{~m} / \mathrm{s}$ vs $2.13 \pm 0.19 ; \mathrm{P}=0.9241)$. There were not enough smokers to assess smoking's impact on TRV.

In the single patient having a clearly abnormal TRV $(2.9 \mathrm{~m} / \mathrm{s})$, closer review of the clinical characteristics were instructive. She was a 47 year old smoker of Italian descent who had undergone splenectomy in childhood. At the time of her abnormal TRV, she had mild diastolic dysfunction $\left(\mathrm{E} / \mathrm{E}^{\prime}\right.$ Ratio=10.1, $\mathrm{E} / \mathrm{A}$ ratio $\left.=2.2\right)$, moderate systolic dysfunction (LV $\mathrm{EF}=42.7 \%$ ), severe cardiac iron overload (cardiac $\mathrm{T} 2 * 6 \mathrm{~ms}$ ), and moderate hepatic iron overload (LIC $=8.5 \mathrm{mg} / \mathrm{g} \mathrm{dw}$ ). At a follow-up echo 21 months later, TRV was normal (2.2 $\mathrm{m} / \mathrm{s}$ ). Her diastolic function was significantly improved ( $\mathrm{E} / \mathrm{A}$ ratio=1.63 and $\mathrm{E} / \mathrm{E}^{\prime}$ Ratio=7.9) while the systolic dysfunction was improved but still present ( $\mathrm{LV} \mathrm{EF}=48.5 \%$ ). Her iron overload was decreased, but still severe in the heart (cardiac T2*9.2 ms) and moderate in the liver ( $\mathrm{LIC}=7.0 \mathrm{mg} / \mathrm{g} \mathrm{dw}$ ). We conclude that her pulmonary hypertension was likely postcapillary, arising from iron cardiomyopathy, that was gradually improving on combined deferiprone and deferoxamine therapy.

\section{DISCUSSION}

The EDICT patient cohort suggests a low risk for pulmonary hypertension in welltransfused thalassemia major patients. Pathologic TR increase was found in one patient and reversed with improved iron chelation. Our finding is in agreement with studies involving optimally treated Italian patients with thalassemia major [15] and [30]. A recent multicenter Italian study reported TRV $>3.0 \mathrm{~m} / \mathrm{s}$ in $5.7 \%$ and RHC confirmed pulmonary hypertension in $2.1 \%$ [31]. However, the prevalence of pulmonary hypertension varies significantly with genotype [32] and [33] and our study cohort was much more ethnically and genetically diverse than the Italian studies. Previous reports from a large American cohort suggested $\mathrm{TRV}>2.5 \mathrm{~m} / \mathrm{s}$ in $33 \%$ of patients and TRV $>3 \mathrm{~m} / \mathrm{s}$ in $5 \%$ [17].

While we were unable to document any TRV suggestive of PH, mild elevations in TRV (2.5 $-2.7 \mathrm{~m} / \mathrm{s}$ ) were relatively common (13\%). TRV was associated with low hemoglobin and high cardiac index, suggesting that increased pulmonary blood flow (to compensate for the anemia [13] and [29]) might account for mild elevations in TRV even if pulmonary vascular resistance is normal. The observation that TRV depends upon cardiac index is well known [34]. Elite athletes have significantly higher TRV at rest than nonathletes, presumably related to their large hearts and increased stroke volumes [35]. Increased TRV's in these athletes are not indicative of any vascular disease. Although TM patients are not typically 
athletes, their resting cardiac dimensions, stroke volumes and cardiac index are all significantly larger than those found in elite athletes; almost half of the patients in this cohort had resting cardiac outputs above the upper limits of normal. As a result, resting TRV of 2.5 - 2.7 may be completely normal for TM patients. However, increased pulmonary blood flow can compromise the normal compliance of pulmonary vasculature by exposing the endothelium to elevated shear forces and mechanical strain [36]. High vessel pulsatility upregulates endothelial arginase, stimulating vascular remodelling. As a result, high pulmonary flow can promote pulmonary vascular disease over a lifetime in some conditions, such as unrepaired atrial septal defects [37] and single pulmonary artery [38]. Thus, further work will be necessary to understand the clinical relevance of these flow-mediated increases in TRV as thalassemia patients age into their fifties, sixties, and seventies.

Similarly, the association of TRV with left ventricular diastolic markers suggests that mild TRV elevations can also result from elevated downstream (post-capillary) filling pressures, rather than changes in pulmonary vascular resistance. $\mathrm{PH}$ is common in non-thalassemic patients with left-sided cardiac disease and has been reported in greater than $60 \%$ of patients with left ventricular systolic dysfunction, greater than $80 \%$ of patients with left ventricular diastolic dysfunction, and in $78 \%$ of patients prior to mitral valve surgery [39] and [40]. In fact, PH frequently develops in response to left-sided cardiac disease due to elevated pulmonary venous pressure and is associated with a series of lesions that range from diseases of the pulmonary veins, mechanical obstruction in the left atrium or at the mitral valve, or to elevation in the left atrial and pulmonary venous pressure due to mitral regurgitation, abnormal left atrial compliance, or to LV diastolic dysfunction [40]. In our TM population, overt ventricular dysfunction was detected in 9 exams, but was associated with a pathological TR jet in only one patient (11.1\%). In fact, TRV and LV EF were uncorrelated. In contrast, both E/A and E/E' ratios were associated with TRV, suggesting that diastolic dysfunction is more important that systolic dysfunction in the development of $\mathrm{PH}$ in TM.

Hemolysis plays a key role in the development of $\mathrm{PH}$ in most hereditary and chronic haemolytic anaemias [41], [42] and [43], through nitric oxide (NO) scavenging, arginine catabolism, and endogenous nitric oxide synthesis inhibition [44] and [45]. Low NO bioavailability produces a vasculopathy characterized by endothelial dysfunction, increased vascular tone, inflammation, and hypercoagulability. Vascular remodeling and destruction of pulmonary vasculature ultimately result in hemolytic anemia-associated PH [46]. However, most red cell destruction in thalassemia major is intramedulary and toxic red cell contents are less likely to be released into the circulation. In fact, we found no significant association between TR jet and two reliable markers of haemolysis: haptoglobin [47] and LDH [48]. A haptoglobin level $<25 \mathrm{mg} / \mathrm{dL}$ was shown to have a high sensitivity and specificity (83\% and 96\%, respectively) in predicting hemolytic disease [49] and serum haptoglobin can be used in the diagnosis of hemolysis in patients receiving multiple units of packed red blood cells [47]. Using the upper limit of $25 \mathrm{mg} / \mathrm{dL}$ for the haptoglobin in our population, hemolysis was present in the $40 \%$ of the cases but no significant $\mathrm{PH}$ was detected in these patients. Our finding is in agreement with the study of Hagar et al who did not find a difference in several markers of haemolysis between TM patients with and 
without PH [16]. It also suggests that significant differences exist between PH in TM and in sickle cell disease [41] and [48].

Further evidence that hemolysis is not central to $\mathrm{PH}$ in well transfused TM patients was the essentially normal global arginine bioavailability index. In SCD, reduced GAB was shown to be independently associated with pulmonary hypertension and increased mortality [50]. Three categories of GAB were defined in that study: high (>0.6254), medium (between 0.3245 and 0.6254$)$ and low $(<0.3245)$. Mean GAB in our patients was $0.81 \pm 0.29$, comparable to values reported in healthy subjects $(0.82 \pm 0.27)$ and higher than the mean value reported in $209 \mathrm{SCD}$ patients $(0.50 \pm 0.26)$ [50]. So, the normal GAB found in TM may explain the significantly lower rate of PH. Paradoxically, TRV retained an association with global arginine bioavailability (GAB). However, arginase is upregulated in non-hemolytic vascular diseases, so GAB is a nonspecific marker of vascular stress [51].

Iron overload is known to impair blood vessel reactivity in thalassemia major [52], [12] and [11] and is correlated with pulmonary hypertension in thalassemia intermedia [53].

However, neither serum ferritin levels, hepatic iron, or cardiac iron were associated to TRV in our study. One possible explanation is that we had so few patients with increased TRV that we could not demonstrate a relationship with iron. Alternatively, regular chelation therapy may have protected the vascular endothelium independently of the organs studied by MRI [12].

Finally, a number of studies showed an association between splenectomy and pulmonary hypertension, both in thalassemia patients [54], [55], [31] and [17] and patients without hemoglobinopathies [56]. Splenectomy leads to increased platelet activation [57] and [44] and red cell microparticles [58], upregulating vascular adhesion molecules and promoting thrombosis. However, in our population TRV was comparable between splenectomised and non-splenectomized patients and no age-effect was observed, counter to the results reported by the Thalassemia Clinical Research Network [17]. A couple of key differences in the patient populations and study design may explain the disparity. Firstly, our patient population was younger, with only five patients older than 40 years of age. Secondly EDICT patients were receiving 2-3 units of blood every three weeks and were within 10 days of their last transfusion, effectively suppressing their ineffective erythropoeisis. In contrast, the TCRN cohort used a cutoff of eight transfusions per year (transfusion interval $<6.5$ weeks), contained a sizable cohort of thalassemia intermedia patients who had initiated chronic transfusion therapy later in life, and studied patients randomly within the transfusion interval; late onset of transfusion therapy is a known risk factor for pulmonary hypertension [59]. Since both the degree of ineffective erythropoeisis [53], and hemoglobin level (the present work) impact TRV, differences in transfusion management and exam timing could explain disparities between the two studies. It should be considered that plasma hemoglobin and microparticle levels are higher in post-splenectomy beta thalassemia patients [59] and [60], but this effect might likely be masked in our well-transfused cohort.

A limitation of this study is that RHC was not performed. However a confirmatory RHC is only recommended for patients with TRV $>3.4 \mathrm{~m} / \mathrm{s}$ or in patients with a TRV between 2.9 
and $3.4 \mathrm{~m} / \mathrm{s}$ in the presence of other signs suggestive of pulmonary hypertension [61] and none of our patients fit that criteria.

\section{CONCLUSIONS}

Well-transfused thalassemia major patients have a low risk for pulmonary hypertension relative to thalassemia intermedia patients. Borderline increases in TRV were associated with a reduced global arginine bioavailability, increased anemia, cardiac index, and diastolic dysfunction but not hemolysis or splenectomy. However, thalassemia major patients do have vascular stressors that raise their potential risk for pulmonary hypertension relative to the general population. Consequently, we support recommendations for annual echocardiographic screening in these patients to assess TRV and diastolic function indices and cardiac catheterization for persistent elevations of TRV above $3 \mathrm{~m} / \mathrm{s}$.

\section{Acknowledgments}

This work supported by the National Heart Lung and Blood Institute (1 RO1 HL075592-01A1) and by the General Clinical Research Centers at Children's Hospital Los Angeles (5 M01 RR00043-43) and Oakland (5 M01 RR-01271).

\section{References}

1. McLaughlin VV, McGoon MD. Pulmonary arterial hypertension. Circulation. 2006; 114:14171431. [PubMed: 17000921]

2. Habib G, Torbicki A. The role of echocardiography in the diagnosis and management of patients with pulmonary hypertension. Eur Respir Rev. 2010; 19:288-299. [PubMed: 21119187]

3. Berger M, Haimowitz A, Van Tosh A, Berdoff RL, Goldberg E. Quantitative assessment of pulmonary hypertension in patients with tricuspid regurgitation using continuous wave Doppler ultrasound. J Am Coll Cardiol. 1985; 6:359-365. [PubMed: 4019921]

4. Barnett CF, Hsue PY, Machado RF. Pulmonary hypertension: an increasingly recognized complication of hereditary hemolytic anemias and HIV infection. Jama. 2008; 299:324-331. [PubMed: 18212317]

5. Aessopos A, Farmakis D. Pulmonary hypertension in beta-thalassemia. Ann N Y Acad Sci. 2005; 1054:342-349. [PubMed: 16339682]

6. Wood JC. Cardiac complications in thalassemia major. Hemoglobin. 2009; 33(Suppl 1):S81-86. [PubMed: 20001637]

7. Morris CR, Vichinsky EP. Pulmonary hypertension in thalassemia. Ann N Y Acad Sci. 2010; 1202:205-213. [PubMed: 20712794]

8. Farmakis D, Aessopos A. Pulmonary hypertension associated with hemoglobinopathies: prevalent but overlooked. Circulation. 2011; 123:1227-1232. [PubMed: 21422398]

9. Aessopos A, Farmakis D, Karagiorga M, Voskaridou E, Loutradi A, Hatziliami A, Joussef J, Rombos J, Loukopoulos D. Cardiac involvement in thalassemia intermedia: a multicenter study. Blood. 2001; 97:3411-3416. [PubMed: 11369631]

10. Patel N, Gonsalves CS, Malik P, Kalra VK. Placenta growth factor augments endothelin-1 and endothelin-B receptor expression via hypoxia-inducible factor-1 alpha. Blood. 2008; 112:856-865. [PubMed: 18411415]

11. Tanner MA, Galanello R, Dessi C, Smith GC, Westwood MA, Agus A, Roughton M, Assomull R, Nair SV, Walker JM, Pennell DJ. A randomized, placebo-controlled, double-blind trial of the effect of combined therapy with deferoxamine and deferiprone on myocardial iron in thalassemia major using cardiovascular magnetic resonance. Circulation. 2007; 115:1876-1884. [PubMed: 17372174] 
12. Cheung YF, Chan GC, Ha SY. Effect of deferasirox (ICL670) on arterial function in patients with beta-thalassaemia major. Br J Haematol. 2008; 141:728-733. [PubMed: 18318756]

13. Aessopos A, Farmakis D, Hatziliami A, Fragodimitri C, Karabatsos F, Joussef J, Mitilineou E, Diamanti-Kandaraki E, Meletis J, Karagiorga M. Cardiac status in well-treated patients with thalassemia major. Eur J Haematol. 2004; 73:359-366. [PubMed: 15458515]

14. Vlahos AP, Koutsouka FP, Papamichael ND, Makis A, Baltogiannis GG, Athanasiou E, Chaliasos N, Bourantas KL, Kolettis TM. Determinants of pulmonary hypertension in patients with Betathalassemia major and normal ventricular function. Acta Haematol. 2012; 128:124-129. [PubMed: 22846514]

15. Aessopos A, Farmakis D, Deftereos S, Tsironi M, Tassiopoulos S, Moyssakis I, Karagiorga M. Thalassemia heart disease: a comparative evaluation of thalassemia major and thalassemia intermedia. Chest. 2005; 127:1523-1530. [PubMed: 15888823]

16. Hagar RW, Morris CR, Vichinsky EP. Pulmonary hypertension in thalassaemia major patients with normal left ventricular systolic function. Br J Haematol. 2006; 133:433-435. [PubMed: 16643452]

17. Morris CR, Kim HY, Trachtenberg F, Wood J, Quinn CT, Sweeters N, Kwiatkowski JL, Thompson AA, Giardina PJ, Boudreaux J, Olivieri NF, Porter JB, Neufeld EJ, Vichinsky EP. Risk factors and mortality associated with an elevated tricuspid regurgitant jet velocity measured by Doppler-echocardiography in thalassemia: a Thalassemia Clinical Research Network report. Blood. 2011; 118:3794-3802. [PubMed: 21772051]

18. Sohn EY, Noetzli LJ, Gera A, Kato R, Coates TD, Harmatz P, Keens TG, Wood JC. Pulmonary function in thalassaemia major and its correlation with body iron stores. Br J Haematol. 2011; 155:102-105. [PubMed: 21810090]

19. Detterich J, Noetzli L, Dorey F, Bar-Cohen Y, Harmatz P, Coates T, Wood J. Electrocardiographic consequences of cardiac iron overload in thalassemia major. Am J Hematol. 2012; 87:139-144. [PubMed: 22052662]

20. Sohn EY, Kato R, Noetzli LJ, Gera A, Coates T, Harmatz P, Keens TG, Wood JC. Exercise performance in thalassemia major: correlation with cardiac iron burden. Am J Hematol. 2013; 88:193-197. [PubMed: 23339082]

21. Nagueh SF, Appleton CP, Gillebert TC, Marino PN, Oh JK, Smiseth OA, Waggoner AD, Flachskampf FA, Pellikka PA, Evangelista A. Recommendations for the evaluation of left ventricular diastolic function by echocardiography. J Am Soc Echocardiogr. 2009; 22:107-133. [PubMed: 19187853]

22. Ommen SR, Nishimura RA, Appleton CP, Miller FA, Oh JK, Redfield MM, Tajik AJ. Clinical utility of Doppler echocardiography and tissue Doppler imaging in the estimation of left ventricular filling pressures: A comparative simultaneous Doppler-catheterization study. Circulation. 2000; 102:1788-1794. [PubMed: 11023933]

23. Dahiya A, Vollbon W, Jellis C, Prior D, Wahi S, Marwick T. Echocardiographic assessment of raised pulmonary vascular resistance: application to diagnosis and follow-up of pulmonary hypertension. Heart. 2010; 96:2005-2009. [PubMed: 21088122]

24. Meloni A, Zmyewski H, Rienhoff HY Jr, Jones A, Pepe A, Lombardi M, Wood JC. Fast approximation to pixelwise relaxivity maps: Validation in iron overloaded subjects. Magn Reson Imaging. 2013; 31:1074-1080. [PubMed: 23773621]

25. Ghugre NR, Enriquez CM, Coates TD, Nelson MD Jr, Wood JC. Improved R2* measurements in myocardial iron overload. J Magn Reson Imaging. 2006; 23:9-16. [PubMed: 16329085]

26. Wood JC, Enriquez C, Ghugre N, Tyzka JM, Carson S, Nelson MD, Coates TD. MRI R2 and R2* mapping accurately estimates hepatic iron concentration in transfusion-dependent thalassemia and sickle cell disease patients. Blood. 2005; 106:1460-1465. [PubMed: 15860670]

27. Meloni A, Rienhoff HY Jr, Jones A, Pepe A, Lombardi M, Wood JC. The use of appropriate calibration curves corrects for systematic differences in liver R2* values measured using different software packages. Br J Haematol. 2013; 161:888-891. [PubMed: 23496418]

28. St Pierre TG, Clark PR, Chua-anusorn W, Fleming AJ, Jeffrey GP, Olynyk JK, Pootrakul P, Robins E, Lindeman R. Noninvasive measurement and imaging of liver iron concentrations using proton magnetic resonance. Blood. 2005; 105:855-861. [PubMed: 15256427] 
29. Meloni A, Detterich J, Berdoukas V, Pepe A, Lombardi M, Coates TD, Wood JC. Comparison of biventricular dimensions and function between pediatric sickle-cell disease and thalassemia major patients without cardiac iron. Am J Hematol. 2013; 88:213-218. [PubMed: 23386313]

30. Derchi G, Fonti A, Forni GL, Galliera EO, Cappellini MD, Turati F, Policlinico OM. Pulmonary hypertension in patients with thalassemia major. Am Heart J. 1999; 138:384. [PubMed: 10426856]

31. Derchi G, Galanello R, Bina P, Cappellini MD, Piga A, Lai ME, Quarta A, Casu G, Perrotta S, Pinto V, Musallam KM, Forni GL. Prevalence and Risk Factors for Pulmonary Arterial Hypertension in a Large Group of beta-Thalassemia Patients Using Right Heart Catheterization: A Webthal Study. Circulation. 2013; 129:338-345. [PubMed: 24081970]

32. Teawtrakul N, Ungprasert P, Pussadhamma B, Prayalaw P, Fucharoen S, Jetsrisuparb A, Pongudom S, Sirijerachai C, Chansung K, Wanitpongpun C, Chuncharunee S. Effect of genotype on pulmonary hypertension risk in patients with thalassemia. Eur J Haematol. 2014; 92:429-434. [PubMed: 24400859]

33. Atichartakarn V, Chuncharunee S, Archararit N, Udomsubpayakul U, Lee R, Tunhasiriwet A, Aryurachai K. Prevalence and risk factors for pulmonary hypertension in patients with hemoglobin E/beta-thalassemia disease. Eur J Haematol. 2014; 92:346-353. [PubMed: 24330103]

34. Bossone E, Rubenfire M, Bach DS, Ricciardi M, Armstrong WF. Range of tricuspid regurgitation velocity at rest and during exercise in normal adult men: implications for the diagnosis of pulmonary hypertension. J Am Coll Cardiol. 1999; 33:1662-1666. [PubMed: 10334439]

35. Bossone E, Vriz O, Bodini BD, Rubenfire M. Cardiovascular response to exercise in elite ice hockey players. Can J Cardiol. 2004; 20:893-897. [PubMed: 15266359]

36. Duke M, Abelmann WH. The hemodynamic response to chronic anemia. Circulation. 1969; 39:503-515. [PubMed: 5778251]

37. Craig RJ, Selzer A. Natural history and prognosis of atrial septal defect. Circulation. 1968; 37:805815. [PubMed: 5646864]

38. Rosenkrantz JG, Carlisle JH, Lynch FP, Vogel JH. Ligation of a single pulmonary artery in the pig: a model of chronic pulmonary hypertension. J Surg Res. 1973; 15:67-73. [PubMed: 4718017]

39. Ghio S, Gavazzi A, Campana C, Inserra C, Klersy C, Sebastiani R, Arbustini E, Recusani F, Tavazzi L. Independent and additive prognostic value of right ventricular systolic function and pulmonary artery pressure in patients with chronic heart failure. Journal of the American College of Cardiology. 2001; 37:183-188. [PubMed: 11153735]

40. Kiefer TL, Bashore TM. Pulmonary hypertension related to left-sided cardiac pathology. Pulm Med. 2011; 2011:381787. [PubMed: 21660234]

41. Gladwin MT, Sachdev V, Jison ML, Shizukuda Y, Plehn JF, Minter K, Brown B, Coles WA, Nichols JS, Ernst I, Hunter LA, Blackwelder WC, Schechter AN, Rodgers GP, Castro O, Ognibene FP. Pulmonary hypertension as a risk factor for death in patients with sickle cell disease. N Engl J Med. 2004; 350:886-895. [PubMed: 14985486]

42. Morris CR, Kuypers FA, Kato GJ, Lavrisha L, Larkin S, Singer T, Vichinsky EP. Hemolysisassociated pulmonary hypertension in thalassemia. Ann N Y Acad Sci. 2005; 1054:481-485. [PubMed: 16339702]

43. Verresen D, De Backer W, Van Meerbeeck J, Neetens I, Van Marck E, Vermeire P. Spherocytosis and pulmonary hypertension coincidental occurrence or causal relationship? Eur Respir J. 1991; 4:629-631. [PubMed: 1936235]

44. Singer ST, Kuypers FA, Styles L, Vichinsky EP, Foote D, Rosenfeld H. Pulmonary hypertension in thalassemia: association with platelet activation and hypercoagulable state. Am J Hematol. 2006; 81:670-675. [PubMed: 16795058]

45. Gladwin MT, Lancaster JR Jr, Freeman BA, Schechter AN. Nitric oxide's reactions with hemoglobin: a view through the SNO-storm. Nat Med. 2003; 9:496-500. [PubMed: 12724752]

46. Gladwin MT, Kato GJ. Cardiopulmonary complications of sickle cell disease: role of nitric oxide and hemolytic anemia. Hematology Am Soc Hematol Educ Program. 2005:51-57. [PubMed: 16304359]

47. Gupta S, Ahern K, Nakhl F, Forte F. Clinical usefulness of haptoglobin levels to evaluate hemolysis in recently transfused patients. Adv Hematol. 2011; 2011:389854. [PubMed: 21860624] 
48. Kato GJ, McGowan V, Machado RF, Little JA, Taylor Jt, Morris CR, Nichols JS, Wang X, Poljakovic M, Morris SM Jr, Gladwin MT. Lactate dehydrogenase as a biomarker of hemolysisassociated nitric oxide resistance, priapism, leg ulceration, pulmonary hypertension, and death in patients with sickle cell disease. Blood. 2006; 107:2279-2285. [PubMed: 16291595]

49. Marchand A, Galen RS, Van Lente F. The predictive value of serum haptoglobin in hemolytic disease. Jama. 1980; 243:1909-1911. [PubMed: 7365971]

50. Morris CR, Kato GJ, Poljakovic M, Wang X, Blackwelder WC, Sachdev V, Hazen SL, Vichinsky EP, Morris SM Jr, Gladwin MT. Dysregulated arginine metabolism, hemolysis-associated pulmonary hypertension, and mortality in sickle cell disease. Jama. 2005; 294:81-90. [PubMed: 15998894]

51. Pernow J, Jung C. Arginase as a potential target in the treatment of cardiovascular disease: reversal of arginine steal? Cardiovasc Res. 2013; 98:334-343. [PubMed: 23417041]

52. Cheung YF, Chan GC, Ha SY. Arterial stiffness and endothelial function in patients with betathalassemia major. Circulation. 2002; 106:2561-2566. [PubMed: 12427652]

53. Musallam KM, Cappellini MD, Wood JC, Motta I, Graziadei G, Tamim H, Taher AT. Elevated liver iron concentration is a marker of increased morbidity in patients with beta thalassemia intermedia. Haematologica. 2011; 96:1605-1612. [PubMed: 21791471]

54. Tam DH, Farber HW. Pulmonary hypertension and beta-thalassemia major: report of a case, its treatment, and a review of the literature. Am J Hematol. 2006; 81:443-447. [PubMed: 16680745]

55. Phrommintikul A, Sukonthasarn A, Kanjanavanit R, Nawarawong W. Splenectomy: a strong risk factor for pulmonary hypertension in patients with thalassaemia. Heart. 2006; 92:1467-1472. [PubMed: 16621878]

56. Peacock AJ. Pulmonary hypertension after splenectomy: a consequence of loss of the splenic filter or is there something more? Thorax. 2005; 60:983-984. [PubMed: 16299113]

57. Atichartakarn V, Angchaisuksiri P, Aryurachai K, Chuncharunee S, Thakkinstian A. In vivo platelet activation and hyperaggregation in hemoglobin E/beta-thalassemia: a consequence of splenectomy. Int J Hematol. 2003; 77:299-303. [PubMed: 12731676]

58. Tantawy AA, Adly AA, Ismail EA, Habeeb NM. Flow cytometric assessment of circulating platelet and erythrocytes microparticles in young thalassemia major patients: relation to pulmonary hypertension and aortic wall stiffness. Eur J Haematol. 2013; 90:508-518. [PubMed: 23506251]

59. Singer ST, Kuypers F, Fineman J, Gildengorin G, Larkin S, Sweeters N, Rosenfeld H, Kurio G, Higa A, Jeng M, Huang J, Vichinsky EP. Elevated tricuspid regurgitant jet velocity in subgroups of thalassemia patients: insight into pathophysiology and the effect of splenectomy. Ann Hematol. 2014; 93:1139-1148. [PubMed: 24577514]

60. Westerman M, Pizzey A, Hirschman J, Cerino M, Weil-Weiner Y, Ramotar P, Eze A, Lawrie A, Purdy G, Mackie I, Porter J. Microvesicles in haemoglobinopathies offer insights into mechanisms of hypercoagulability, haemolysis and the effects of therapy. Br J Haematol. 2008; 142:126-135. [PubMed: 18422994]

61. Galie N, Hoeper MM, Humbert M, Torbicki A, Vachiery JL, Barbera JA, Beghetti M, Corris P, Gaine S, Gibbs JS, Gomez-Sanchez MA, Jondeau G, Klepetko W, Opitz C, Peacock A, Rubin L, Zellweger M, Simonneau G. Guidelines for the diagnosis and treatment of pulmonary hypertension: the Task Force for the Diagnosis and Treatment of Pulmonary Hypertension of the European Society of Cardiology (ESC) and the European Respiratory Society (ERS), endorsed by the International Society of Heart and Lung Transplantation (ISHLT). Eur Heart J. 2009; 30:24932537. [PubMed: 19713419] 


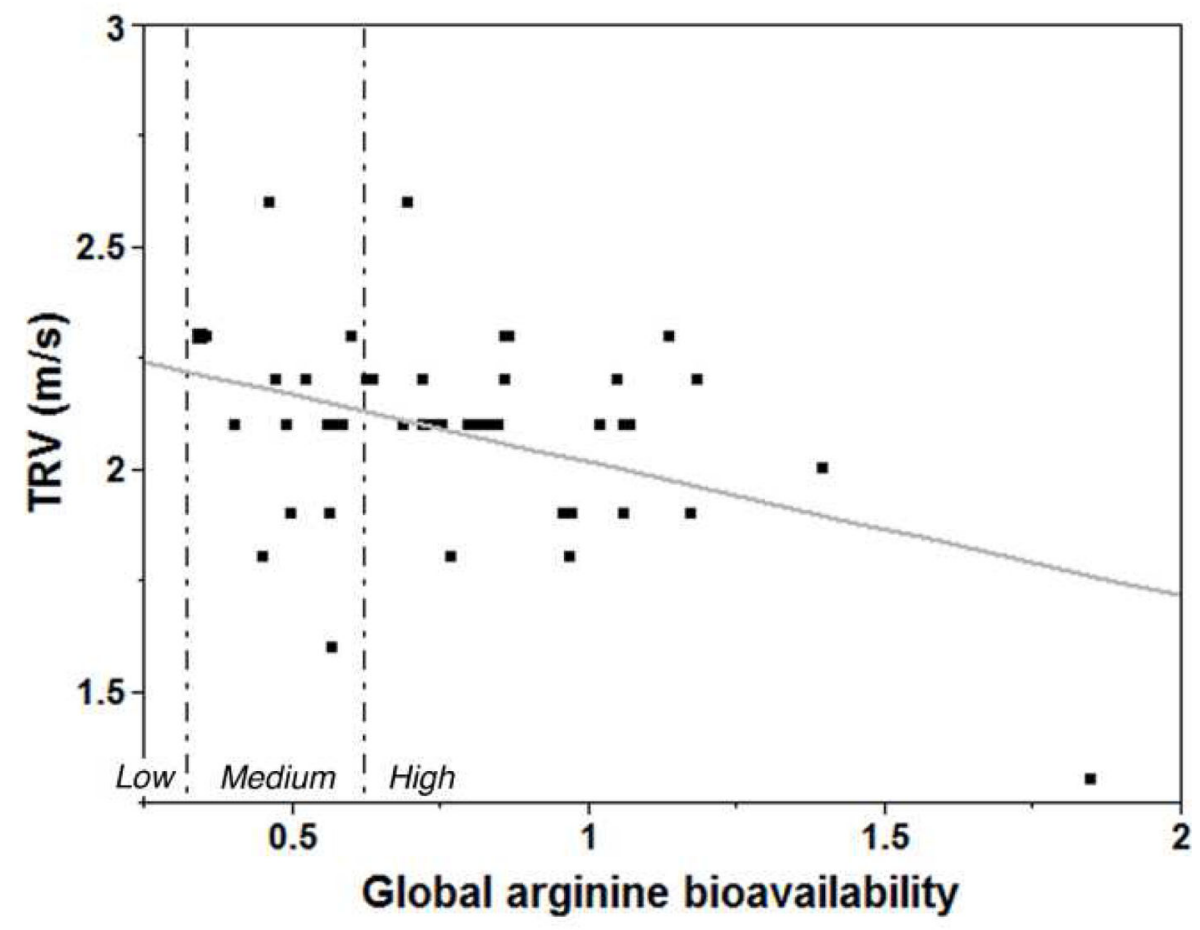

Figure 1.

Scatter plot and fitted regression line showing the relationship between TRV and global arginine bioavailability (GAB). Thresholds proposed by Morris et al. are shown; no patient has decreased GAB. 

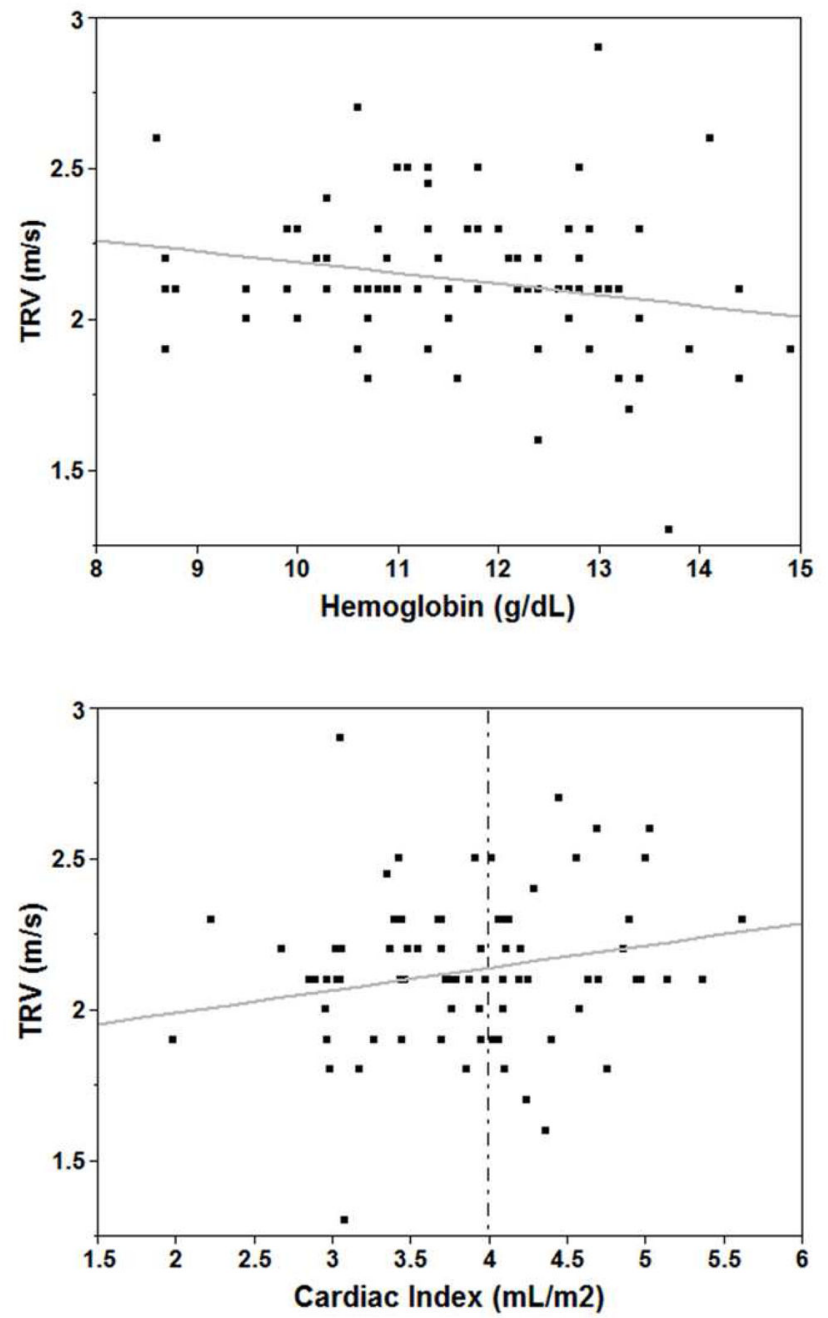

Figure 2.

Scatter plot and fitted regression line showing the relationship between TRV and hemoglobin (up) and between TRV and cardiac index (bottom). 

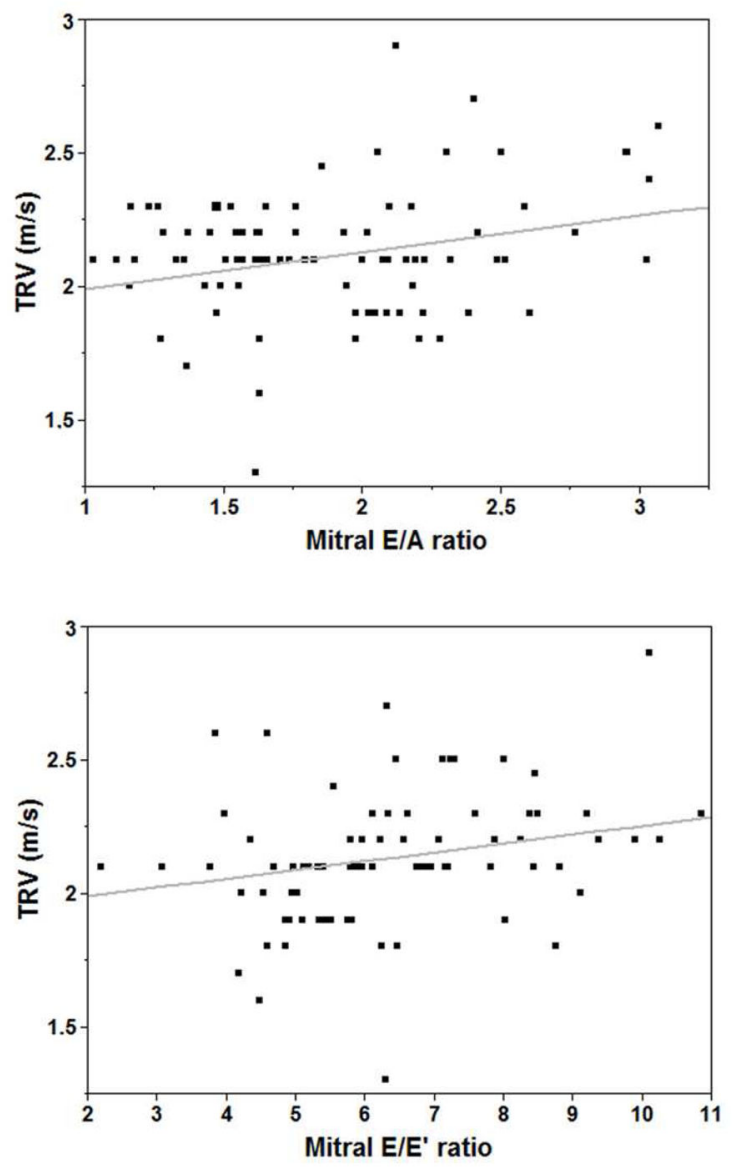

Figure 3.

Scatter diagram and regression line of TRV compared to E/A ratio (up) and $\mathrm{E} / \mathrm{E}^{\prime}$ ratio (bottom); $\mathrm{E} / \mathrm{E}^{\prime}>10$ is considered evidence of diastolic dysfunction. 
Table 1

Associations with TRV.

\begin{tabular}{|c|c|c|c|}
\hline \multirow[t]{2}{*}{ Variable } & \multirow[t]{2}{*}{ Mean \pm SD } & \multicolumn{2}{|c|}{ Correlation with TRV } \\
\hline & & $\mathbf{R}$ & P-value \\
\hline Age & $25.53 \pm 8.04$ & 0.002 & 0.9828 \\
\hline \multicolumn{4}{|l|}{ Hemolysis } \\
\hline Haptoglobin (mg/dL) & $34.02 \pm 22.61$ & -0.032 & 0.7702 \\
\hline LDH (U/L) & $443.53 \pm 178.37$ & 0.151 & 0.2341 \\
\hline Global arginine bioavailability & $0.81 \pm 0.29$ & -0.399 & 0.0050 \\
\hline \multicolumn{4}{|l|}{ Anemia } \\
\hline Hemoglobin (g/dL) & $11.75 \pm 1.24$ & -0.219 & 0.0461 \\
\hline Hematocrit $(\%)$ & $35.14 \pm 3.73$ & -0.195 & 0.0771 \\
\hline Cardiac Index $\left(\mathrm{L} / \mathrm{min} / \mathrm{m}^{2}\right)$ & $3.88 \pm 0.63$ & 0.223 & 0.0481 \\
\hline \multicolumn{4}{|l|}{ Hypoxia } \\
\hline TLC (\% of predicted) & $94.06 \pm 11.69$ & 0.182 & 0.1079 \\
\hline Resting Saturation O2 (\%) & $96.95 \pm 1.13$ & 0.068 & 0.5618 \\
\hline $\mathrm{O}_{2}$ saturation during exercise $(\%)$ & $93.77 \pm 4.08$ & 0.165 & 0.1759 \\
\hline Adjusted DLCO & $5.43 \pm 0.87$ & 0.126 & 0.2797 \\
\hline \multicolumn{4}{|l|}{ Systolic function } \\
\hline LV EDVI $\left(\mathrm{mL} / \mathrm{m}^{2}\right)$ & $91.76 \pm 15.38$ & 0.109 & 0.3268 \\
\hline LV ESVI $\left(\mathrm{mL} / \mathrm{m}^{2}\right)$ & $34.95 \pm 8.89$ & 0.017 & 0.8815 \\
\hline $\operatorname{LVEF}(\%)$ & $62.34 \pm 5.18$ & 0.179 & 0.1063 \\
\hline LV mass index $\left(\mathrm{g} / \mathrm{m}^{2}\right)$ & $69.58 \pm 11.77$ & 0.036 & 0.7507 \\
\hline \multicolumn{4}{|l|}{ Diastolic function } \\
\hline MV E/A & $1.94 \pm 0.42$ & 0.289 & 0.0088 \\
\hline $\mathrm{MV} \mathrm{E} / \mathrm{E}^{\prime}$ & $6.16 \pm 1.40$ & 0.223 & 0.0453 \\
\hline \multicolumn{4}{|l|}{ Iron } \\
\hline Serum ferritin (ng/L) & $2789.42 \pm 2477.51$ & -0.096 & 0.3852 \\
\hline Cardiac R2* (Hz) & $97.43 \pm 73.13$ & -0.166 & 0.1338 \\
\hline LIC (mg/g dw) & $11.69 \pm 9.19$ & -0.079 & 0.4796 \\
\hline
\end{tabular}

